\title{
PERAN KEPERCAYAAN NASABAH DALAM MEMEDIASI PENGARUH KUALITAS PELAYANAN TERHADAP KEPUASAN NASABAH
}

\author{
Ida Bagus Ngurah Satwika Purwa ${ }^{1}$ \\ I Gusti Agung Ketut Sri Ardani² \\ ${ }^{1,2}$ Fakultas Ekonomi dan Bisnis Universitas Udayana, Bali, Indonesia \\ e-mail: chandrasurya616i@yahoo.com
}

\begin{abstract}
ABSTRAK
Tujuan penelitian ini adalah untuk mengetahui peran kepercayaan nasabah dalam memediasi pengaruh kualitas pelayanan terhadap kepuasan nasabah. Penelitian ini dilakukan di PT. Satwika Purwa Negara yang merupakan kantor pemasaran mandiri dari Prudential Indonesia. Jumlah nasabah yang dilayani di PT. Satwika Purwa Negara mencapai 8000 lebih nasabah. Jumlah sampel yang diambil adalah 100 orang, menggunakan teknik non probability sampling dengan path sebagai teknik analisis data. Berdasarkan hasil analisis ditemukan bahwa kualitas pelayanan berpengaruh signifikan terhadap kepercayan nasabah pada PT. Satwika Purwa Negara, semakin baik tingkat kualitas pelayanan maka semakin tinggi kepercayaan yang diperoleh nasabah. Kepercayaan nasabah berpengaruh signifikan terhadap kepuasan nasabah PT. Satwika Purwa Negara, semakin tinggi kepercayaan nasabah, maka kepuasan nasabah semakin mudah didapatkan. Kualitas pelayanan berpengaruh signifikan terhadap kepuasan nasabah PT. Satwika Purwa Negara, maka semakin baik tingkat pelayanan yang diberikan maka kepuasan nasabah dapat tercipta. Kepercayaan nasabah merupakan variabel intervening yang menghubungkan kualitas pelayanan dengan kepuasan nasabah pada PT. Satwika Purwa Negara.
\end{abstract}

Kata Kunci: kualitas pelayanan, kepercayaan nasabah, kepuasan nasabah.

\begin{abstract}
The purpose of this study is to determine the role of customer confidence in mediating the influence of service quality on customer satisfaction. This research was conducted at PT. Satwika Purwa Negara which is an independent marketing office of Prudential Indonesia. Number of customers served in PT. Satwika Purwa Negara reaches 8000 more customers. The number of samples taken is 100 people, using technique of non probability sampling with path as technique of data analysis. Based on the results of the analysis found that the quality of service significantly influence the belief customer at PT. Satwika Purwa Negara, the better the level of service quality, the higher the trust obtained by the customer. Customer confidence has a significant effect on customer satisfaction of PT. Satwika Purwa Negara, the higher the customer's trust, the more easily available customer satisfaction. Quality of service significantly influence customer satisfaction PT. Satwika Purwa Negara, the better the level of service provided then customer satisfaction can be created. Customer confidence is an intervening variable that connects service quality with customer satisfaction at PT. Satwika Purwa Negara.
\end{abstract}

Keywords: service quality, customer trust, customer satisfaction. 


\section{PENDAHULUAN}

Asuransi pada masa sekarang sudah sangat lumrah di kalangan masyarakat. Dalam perencanaan keuangan asuransi memiliki peranan yang besar dalam kehidupan masyarakat, utamanya dalam melindungi asset asset yang dimiliki dari dampak kerugian akibat resiko tertentu. Secara garis besar asuransi di Indonesia terdapat 2 jenis, yakni asuransi umum dan asuransi jiwa. Asuransi umum memberikan perlindungan terhadap kerugian dari resiko yang dapat terjadi pada benda benda berharga, seperti mobil, rumah, akibat kecelakaan ataupun kebakaran. Sedangkan asuransi jiwa, memberikan perlindungan terhadap kerugian yang timbul akibat resiko yang mengancam jiwa seseorang, seperti sakit, kecelakaan, maupun meninggal dunia. Pada perusahaan yang bergerak dibidang jasa yang berorientasi kepada kepuasan nasabah (pelanggan), perusahaan harus senantiasa memperhatikan komunikasi dengan menjalin kegiatan pelayanan yang prima yang dapat merangsang pembelian dan kepuasan pelanggan.

Kualitas pelayanan dan kepuasan pelanggan adalah konsep yang berbeda dengan argumen bahwa kualitas pelayanan yang dipersepsikan merupakan suatu bentuk sikap, evaluasi menyeluruh dalam jangka panjang, sedangkan kepuasan menunjukan ukuran transaksi tertentu. Oleh karena itu, kepuasan berlangsung dalam jangka pendek. Semakin tinggi tingkat kualitas pelayanan yang dipersepsikan, semakin meningkatnya kepuasan konsumen. Kualitas memberikan dorongan kepada pelanggan untuk menjalin hubungan yang erat dengan perusahaan sehingga memungkinkan perusahaan untuk memahami dengan seksama harapan dan kebutuhan (Prabowo, 2010). 
Jasa pelayanan yang dilaksanakan perusahaan tersebut dalam upaya untuk memberikan rasa kepuasan, menimbulkan kapercayaan terhadap pihak nasabah, yang merupakan prioritas utama dari penerapan pelayanan yang prima, karena kepuasan pelanggan adalah tingkat perasaan seseorang setelah melihat dan merasakan kinerja hasil yang dia dapatkan. Penelitian dari Rizan (2011), bahwa kualitas pelayanan sangat penting dipertahankan untuk mendapatkan kepuasan pelanggan. Usaha yang bergerak di bidang jasa, pelayanan kepada nasabah memegang peranan penting. Kualitas pelayanan harus selalu dijaga dan ditingkatkan untuk meningkatkan kepuasan nasabah. Perbankan yang bergerak di bidang jasa harus bisa memberikan pelayanan yang memuaskan nasabahnya, sehingga nasabah akan meningkatkan loyalitasnya pada perbankan. Peranan manajemen dituntut untuk bisa meningkatkan kualitas pelayanan bagi nasabah. Kualitas pelayanan bisa diwujudkan apabila manajemen perbankan memahami faktor-faktor yang mempengaruhi kualitas pelayanan. Faktor-faktor yang mempengaruhi kualitas pelayanan yang dikembangkan Parasuraman (2001).

Definisi kulitas menurut Kotler (2009) adalah "seluruh ciri serta sifat suatu produk atau pelayanan yang berpengaruh pada kemampuan untuk memuaskan kebutuhan yang dinyatakan atau yang tersirat". Ini jelas merupakan definisi kualitas yang berpusat pada konsumen. Seorang produsen dapat memberikan kualitas bila produk atau pelayanan yang diberikan dapat memenuhi atau melebihi harapan nasabah berdasarkan beberapa pengertian kualitas diatas dapat diartikan bahwa kualitas hidup kerja harus merupakan suatu pola pikir (mindset), yang dapat menterjemahkan tuntutan dan kebutuhan pasar nasabah dalam suatu proses 
manajemen dan proses produksi barang atau jasa terus menerus tanpa hentinya sehingga memenuhi persepsi kualitas pasar konsumen tersebut.

Persepektif kualitas yaitu pendekatan yang digunakan untuk mewujudkan kualitas suatu produk atau jasa. Seiring perkembangan jaman, asuransi juga mengalami perubahan dan penyempurnaan. Saat ini selain memberikan perlindungan terhadap kerugian dari resiko yang mengancam jiwa, asuransi jiwa juga dapat dijadikan sebagai alternative perencaaan keuangan jangka panjang. Jika dahulu asuransi hanya dapat memberikan manfaat saat terjadi resiko kecelakaan ataupun meninggal dunia, kini asuransi juga menerapkan system unit link yang menggabungkan manfaat proteksi asuransi dengan manfaat investasi atau tabungan. Hal ini menjadikan asuransi memiliki manfaat yang lebih banyak.

Asuransi dapat dijadikan sebagai alternatif perencanaan dana pensiun, dana pendidikan, dana warisan maupun untuk dana darurat kesehatan. Perubahan konsep asuransi juga berdampak terhadap bisnis asuransi, perkembangan asuransi terus meningkat setiap tahunnya. Resiko kehidupan yang ada seperti sakit, kecelakaan, cacat, meninggal ditambah dengan krisis keuangan yang terjadi, meningkatnya biaya kesehatan, biaya pendidikan dan kebutuhan di usia pensiun memacu kesadaran masyarakat memiliki perencanaan keuangan dengan berinvestasi dan membeli produk asuransi jiwa. Asuransi jiwa juga banyak berkembang di Indonesia, terlihat dari banyaknya perusahaan asuransi jiwa yang berdiri dan beroperasi di seluruh negeri. Tidak hanya dari dalam negeri, perusahaan global juga sudah masuk dan membuka bisnisnya di Indonesia. Lebih dari 100 perusahaan asuransi yang tercatat dan diawasi oleh Otoritas Jasa 
keuangan (OJK) dan Asosiasi Asuransi Jiwa Indonesia (AAJI), 50 diantaranya adalah perusahaan asuransi jiwa (data OJK per 31 Desember 2016). Sejak pemodal asing diperbolehkan masuk ke bisnis asuransi 3 dekade lalu, minat perusahaan asuransi asing untuk beroperasi di Indonesia terus meningkat meski harus bermitra dengan perusahaan lokal. Sebut saja Prudential Indonesia, AXA Mandiri, AIA, Allianz, Tokio Marine adalah beberapa contoh dari perusahaan asuransi jiwa di Indonesia dan masih banyak perusahaan lainnya.

Banyaknya pemain di industri asuransi tak urung membuat persaingan di industri ini semakin ketat. Tak hanya persaingan dalam pasar juga dalam persaingan merekrut sumber daya. Dengan demikian persaingan di industri asuransi kian tajam seiring dengan makin banyaknya pemain asuransi yang berkiprah di bidang asuransi jiwa. Meski persaingan cukup tajam perkembangan asuransi jiwa Indonesia meningkat di setiap tahunnya, ini menunjukkan bahwa industri asuransi jiwa di Indonesia memiliki potensi yang sangat besar dan kesadaran masyarakat Indonesia terhadap pentingnya asuransi jiwa juga terus meningkat (Sumber : www.frontier.com). Pangsa pasar yang masih sangat besar, yakni lebih dari $90 \%$ dari total penduduk di Indonesia yang belum memiliki proteksi asuransi dan kurang dari 8\% penduduk yang berasuransi (Data AAJI per 2016). Potensi ini masih begitu besar menjadikan perusahaan perusahaan asuransi semakin kreatif dalam memikat hati nasabah. Produk produk asuransi pun semakin bervariatif, dan berbeda beda di setiap perusahaan. Dengan banyaknya perusahaan dan produk asuransi yang ada menuntut masyarakat untuk semakin selektif dalam memilih perusahaan dan produk asuransi, ini dilakukan masyarakat 
untuk mendapatkan jaminan produk proteksi yang berkualitas dan terhindar dari persoalan finansial.

Disisi lain tuntutan akan pelayanan yang baik juga menjadi tantangan tersendiri bagi perusahaan asuransi jiwa. Salah satu syarat agar dapat unggul dalam persaingan tentu dengan tetap dapat menciptakan serta mempertahankan nasabah yang membeli atau menggunakan jasa asuransi dari perusahaan. Adapun pra survei yang dilakukan terhadap beberapa nasabah, mengenai bagaimana pelayanan kami kepada para nasabah yang telah kami berikan, mereka sangat senang dan puas dengan bagaimana pelayanan kami kepada para nasabah, sehingga sangat memudahkan nasabah jika ingin melakukan klaim atau apapun kondisi asurunsai yang dihadapi saat itu. Pernyataan yang sama juga sering diberikan pada nasabah nasabah lainya, adapun beberapa kendala yang sering dihadapi oleh beberapa nasabah, seperti keraguan yang disebabkan banyaknya penipuan yang dilakukan oleh oknum oknum tidak bertanggung jawab, dapat dijelaskan secara terperinci dan jelas oleh para agent asuransi.

Kondisi tersebut tentu akan terjadi apabila perusahaan dapat menciptakan dan meningkatkan kepercayaan dan kepuasan bagi nasabah sehingga nasabah membeli dan bertahan dengan perusahaan yang bersangkutan. Tahap awal pembelian asuransi tentu atas landasan kepercayaan. Perusahaan yang dapat membuat nasabah percaya dengan produk dan jasa yang dimiliki akan mebuat nasabah merasa puas karena mempercayakan keuangannya dikelola oleh perusahaan yang terpercaya. Selain itu perusahaan yang dapat memberikan pelayanan yang baik tentu akan membuat nasabah merasa puas karena kebutuhan 
nasabah terpenuhi dan terlayani dengan baik. Dengan pelayanan yang memuaskan dari perusahaan asuransi maka kepercayaan nasabah terhadap perusahaan asuransi semakin meningkat. Dengan tingkat kepercayaan, kualitas pelayanan serta kepuasan nasabah yang semakin baik akan memberikan dampak positif bagi perusahaan. Perusahaan yang mampu memberikan komitmennya kepada nasabah dengan masing masing profilnya tentu akan memiliki integritas di mata nasabah dan calon nasabah sehingga dapt menciptakan dan meningkatkan kepercayaan dari calon nasabah untuk membeli dan menggunakan produk dari perusahaan asuransi jiwa yang bersangkutan.

Salah satu cara agar penjualan produk dan jasa perusahaan lebih unggul dibandingkan dengan para pesaingnya adalah dengan memberikan pelayanan yang berkualitas yang memenuhi kebutuhan dari nasabah dan dapat memuaskan nasabah. Dalam penelitiannya (Parasuraman, 2001) menyatakan bahwa semakin baik mutu layanan yang diberikan oleh perusahaan akan membuat konsumen puas dengan pelayanan dari perusahaan. Layanan yang baik adalah layanan yang dilakukan dengan tanggap, sigap, ramah dan cepat. Dengan memberikan pelayanan, menimbulkan rasa senang atas pelayanan dan nilai lebih dalam pelayanan akan membuat nasabah puas.

Perusahaan asuransi jiwa yang ada di Indonesia salah satunya Prudential Indonesia, merupakan perusahaan asuransi terbaik (majalah investor). Sebagai asuransi terbaik tentu tingkat kepuasan nasabah dan kepercayaan nasabah sangat tinggi terhadap pelayanan dan produk yang dimiliki Prudential Indonesia. Sebagai asuransi terbaik Prudential telah memiliki lebih dari ratusan juta nasabah yang 
dilayani oleh 6 kantor cabang di seluruh Indonesia. Untuk memaksimalkan pelayanan terhadap nasabah, Prudential Indonesia memberikan kesempatan kepada tenaga pemasarannya yang telah mencapai posisi Agency Director untuk membuka Kantor Pemasaran Mandiri di daerah masing masing dengan syarat minimum omzet penjualan group 5 Milyar, dan kini sudah berdiri lebih dari 250 kantor pemasaran mandiri dari Aceh hingga Papua. Di Provinsi Bali, sudah berdiri lebih dari 20 kantor pemasaran mandiri. Salah satunya adalah PT. Satwika Purwa Negara.

Penelitian ini dilakukan di PT. Satwika Purwa Negara yang merupakan kantor pemasaran mandiri dari Prudential Indonesia. PT. Satwika Purwa Negara resmi didirikan pada tanggal 20 Mei 2013 dan telah berdiri lebih dari 4 tahun hingga sekarang. Dalam perjalanannya hingga saat ini jumlah nasabah yang dilayani di PT. Satwika Purwa Negara mencapai 8000 lebih nasabah. Hal ini menunjukkan bahwa hingga kini perusahaan telah mampu memberikan pelayanan mampu memuaskan nasabah baik dari sisi Tangibles, artinya kualitas pelayanan yang berupa sarana fisik perkantoran, ruang tunggu, dan lain-lain, Reliability, yakni kemampuan dan kehandalan untuk menyediakan pelayanan yang terpercaya. Responsiveness, yakni kesanggupan untuk membantu dan menyediakan pelayanan secara cepat dan tepat, serta tanggap terhadap keinginan nasabah. Assurance, yakni kemampuan dan keramahan serta sopan santun pegawai dalam meyakinkan dan menumbuhkan kepercayaan nasabah. Emphaty, yakni sikap tegas tetapi penuh perhatian dari pegawai terhadap nasabah. Nasabah akan merasa puas dengan adanya jaminan / kepuasan bahwa layanan yang mereka 
terima benar dan dilakukan oleh sumber daya manusia yang berkompeten di bidangnya (Syamsi, 2008). Dalam kurun 4 tahun tentu terjadi pasang surut dalam perkembangan perusahaan. Dibawah ini merupakan data perkembangan produksi PT. Satwika Purwa Negara semenjak perusahaan berdiri pada tahun 2013.

Tabel 1.

Perkembangan Total Pendapatan Premi Nasabah Asuransi PT. Satwika Purwa Negara tahun 2013 sampai 2016

\begin{tabular}{ccc}
\hline No & Tahun & Total Premi (Dalam miliaran Rupiah) \\
\hline 1 & 2013 & $8,220,877,000$ \\
2 & 2014 & $9,160,060,000$ \\
3 & 2015 & $8,845,295,000$ \\
4 & 2016 & $6,260,986,000$ \\
\hline
\end{tabular}

Sumber: PT. Satwika Purwa Negara, 2017

Tabel pendapatan premi dari tahun 2013 sampai 2016 diatas menunjukan bahwa adanya trend penurunan hasil premi dari agency bersama dengan beberapa leader yang ada di perusahaan. Peneliti ingin mengetahui apa yang menyebabkan terjadinya penurunan pendapatan premi dan apakah ada peran kepercayaan nasabah dalam memediasi pengaruh kualitas pelayanan terhadap kepuasan nasabah PT Satwika Purwa Negara.

Penilaian terhadap kualitas pelayanan bukan didasarkan atas pengakuan atau penilaian dari pemberi pelayanan, tetapi diberikan oleh langganan atau pihak yang menerima pelayanan. Namun demikian, tidak ada suatu standar yang dapat dipakai sebagai ukuran umum tentang kualitas pelayanan. Hal ini disebabkan unsur subyektivitas dalam diri penerima pelayanan, seseorang mungkin menilai suatu pelayanan yang diterimanya sudah memuaskan tetapi belum memuaskan bagi orang lain. 
Kualitas merupakan suatu kondisi dinamis yang berpengaruh dengan produk, jasa, manusia, proses dan lingkungan yang memenuhi atau melebihi harapan (Tjiptono, 2007). Sehingga definisi kualitas pelayanan dapat diartikan sebagai upaya pemenuhan kebutuhan dan keinginan konsumen serta ketepatan penyampaiannya dalam mengimbangi harapan konsumen (Tjiptono, 2007).

Kualitas pelayanan (service quality) dapat diketahui dengan cara membandingkan persepsi para konsumen atas pelayanan yang nyata-nyata mereka terima / peroleh dengan pelayanan yang sesungguhnya mereka harapkan / inginkan terhadap atribut-atribut pelayanan suatu perusahaan. Jika jasa yang diterima atau dirasakan (perceived service) sesuai dengan yang diharapkan, maka kualitas pelayanan dipersepsikan baik dan memuaskan, jika jasa yang diterima melampaui harapan konsumen, maka kualitas pelayanan dipersepsikan sangat baik dan berkualitas. Sebaliknya jika jasa yang diterima lebih rendah daripada yang diharapkan, maka kualitas pelayanan dipersepsikan buruk.

Pelayanan adalah setiap tindakan atau kegiatan yang dapat ditawarkan oleh suatu pihak kepada pihak lain, yang pada dasarnya tidak berwujud dan tidak mengakibatkan kepemilikan apapun. Produksinya dapat dikaitkan atau tidak dikaitkan pada satu produk fisik. Pelayanan merupakan perilaku produsen dalam rangka memenuhi kebutuhan dan keinginan konsumen demi tercapainya kepuasan pada konsumen itu sendiri. Kotler juga mengatakan bahwa perilaku tersebut dapat terjadi pada saat, sebelum dan sesudah terjadinya transaksi. Pada umumnya pelayanan yang bertaraf tinggi akan menghasilkan kepuasan yang tinggi serta pembelian ulang yang lebih sering. 
Penelitian yang dilakukan oleh Pramana dan Rastini (2016) yang berjudul Pengaruh Kualitas Pelayanan Terhadap Kepercayaan Nasabah Dan Loyalitas Nasabah Bank Mandiri Cabang Veteran Denpasar Bali, menyebutkan bahwa adanya pengaruh positif dan signifikan antara kualitas pelayanan terhadap kepercayaan. Penelitian yang dilakukan oleh Agustiono dan Sumarno (2006); Wang I- Ming dan Shieh (2006); Aryani dan Rosinta (2010); Paramitha dkk. (2013) menghasilkan bahwa semakin tinggi tingkat kualitas pelayanan yang diberikan maka semakin tinggi pula kepercayaan yang diterima oleh nasabah pada suatu perusahaan. Haryono (2010) dalam penelitiannya mengenai internet banking menyebutkan terdapat pengaruh yang signifikan dari variabel kualitas pelayanan internet banking terhadap kepercayaan nasabah pada penggunaan internet banking.

$\mathrm{H}_{1}$ : Kualitas pelayanan berpengaruh secara positif dan signifikan terhadap kepercayaan nasabah.

Kepercayaan (trust) sangat penting untuk membangun dan membina hubungan jangka panjang menurut Rousseau et al. 1998 (yang dikutip oleh Akbar dan Parvez, 2009). Kepercayaan diyakini memiliki peran yang penting dalam mempengaruhi komitmen (Morgan, 1994). Kepercayaan adalah keyakinan bahwa penyedia jasa dapat menggunakannya sebagai alat untuk menjalin hubungan jangka panjang dengan nasabah yang akan dilayani.

Kepercayaan adalah suatu kemauan atau keyakinan mitra pertukaran untuk menjalin hubungan jangka panjang untuk menghasilkan kerja yang positif (Gatot dan Purwanto, 2004). Kepercayaan ada ketika sebuah kelompok percaya pada 
sifat terpercaya dan integritas mitra. Kepercayaan adalah ekspektasi yang dipegang oleh individu bahwa ucapan seseorang dapat diandalkan. Kelompok terpercaya perlu memiliki integritas tinggi dan dapat dipercaya, yang diasosiasikan, dengan kualitas yaitu: konsisten, kompeten, jujur, adil, bertanggung jawab, suka membantu dan baik (Morgan dan Hunt, 1994 dalam Gatot dan Purwanto, 2004). Kemampuan berkomunikasi yang efektif merupakan instrumen untuk menghasilkan kepercayaan nasabah. Komunikasi yang efektif akan membantu nasabah untuk meningkatkan pengetahuan dan pemahaman tentang pentingnya menciptakan kepercayaan pada perusahaan penyedia jasa, karena komunikasi yang sering dan bermutu tinggi akan menghasilkan kepercayaan yang lebih besar (Morgan \& Hunt, 1994 dalam Gatot Yulianto dan Purwanto Waluyo, 2004). Secara umum, "kepuasan (satisfication) adalah perasaan senang atau kecewa seseorang yang timbul karena membandingkan kinerja yang dipersepsikan produk (atau hasil) terhadap ekspektasi mereka. Jika kinerja gagal memenuhi ekspektasi, nasabah akan tidak puas. Jika kinerja sesuai dengan ekspektasi, nasabah akan puas. Jika kinerja melebihi ekspektasi, nasabah akan sangat puas atau senang".

Menurut Tjiptono (2011) kepuasan adalah perasaan yang timbul setelah mengevaluasi pengalaman pemakaian produk. Penelitian yang dilakukan oleh Wardani (2015) mengenai Pengaruh Kepercayaan Dan Kepuasan Terhadap Loyalitas Jamaah Umroh Pt. Nur Ramadhan Yogyakarta membuktikan bahwa adanya hubungan yang positif antara kepercayaan terhadap kepuasan nasabah. Dan penelitian yang dilakukan oleh Arifin (2011) mengenai Pengaruh 
Ida Bagus Ngurah Satwika Purwa Peran Kepercayaan...

Kepercayaan, Fasilitas Dan Kualitas Pelayanan Terhadap Kepuasan Konsumen Pada Hotel Jepara Indah membuktikan bahwa kepercayaan berpengaruh positif terhadap kepuasan nasabah.

$\mathrm{H}_{2}$ : Kepercayaan nasabah berpengaruh positif dan signifikan terhadap kepuasan nasabah

Penelitian yang dilakukan Aryani dan Rosita (2010) mengenai pengaruh kualitas layanan terhadap kepuasan pelanggan dalam membentuk Loyalitas Pelanggan membuktikan bahwa kualitas pelayanan berpengaruh positif dan signifikan terhadap kepuasan pelanggan. Begitu pula terdapat beberapa penelitian empiris yang mendukung bahwa kualitas layanan berpengaruh terhadap kepuasan dalam perbankan (Caruana, 2002) membuktikan bahwa terdapat hubungan yang erat antara kualitas layanan dan kepuasan.

$\mathrm{H}_{3}$ : Kualitas pelayanan berpengaruh positif dan signifikan terhadap kepuasan nasabah.

Penelitian yang dilakukan oleh Santosa (2011) membuktikan bahwa pengaruh kualitas pelayanan terhadap kepuasan nasabah dengan kepercayaan sebagai variable mediasi berpengaruh positif dan signifikan. Penelitian yang dilakukan oleh Lyle (2002), yang berjudul Trust, Satisfaction and Loyalty in Customer Reliationship Management: An Application of Justice Theory, hasilnya menunjukkan bahwa kepercayaan mampu memperkuat pengaruh kepuasan terhadap loyalitas nasabah.

$\mathrm{H}_{4}$ : Peran kepercayaan nasabah mampu memediasi pengaruh kualitas pelayanan terhadap kepuasan nasabah. 


\section{METODE PENELITIAN}

Lokasi penelitian dilakukan di wilayah Kota Denpasar. Kota Denpasar dipilih sebagai lokasi penelitian karena kota Denpasar merupakan pusat kota dan mencakup juga pusat bisnis sehingga mobilitas penduduk tinggi dan mengakibatkan kebutuhan akan layanan juga semakin tinggi, dengan adanya kantor operasional di Denpasar dikarenakan dominan para nasabah, admin, agent, maupun leadernya berasal dari Denpasar, sehingga kantor operasional yang berletak di jalan Gunung Merapi nomer 21 Denpasar, Bali sangatlah tepat bagi pemecahan masalah jika terjadi atau keluhan para nasabah yang membutuhkan respon cepat untuk di tanggapi.

Adapun Subjek dan Objek penelitian ini adalah bagaimana kepercayaan nasabah dapat memediasi pengaruh kualitas pelayanan agency terhadap kepuasan nasabah. Karena menurut saya adanya kecenderungan peningkatan kepercayaan nasabah yang dapat dipengar uhi oleh pelayanan yang baik sehingga kepuasan nasabah akan terpenuhi. Variabel-variabel dalam penelitian ini terdiri dari variabel eksogen yaitu kualitas pelayanan (X), variabel mediasi yaitu kepercayaan $\left(\mathrm{Y}_{1}\right)$ dan variabel endogen yaitu kepuasan konsumen $\left(\mathrm{Y}_{2}\right)$.

Pelayanan adalah setiap tindakan atau kegiatan yang dapat ditawarkan oleh suatu pihak kepada pihak lain, yang pada dasarnya tidak berwujud dan tidak mengakibatkan kepemilikan apapun. Kualitas pelayanan dapat diartikan sebagai upaya pemenuhan kebutuhan dan keinginan konsumen serta ketepatan penyampaiannya dalam mengimbangi harapan konsumen. Zeithaml., et., al (2013). Kepercayaan pada penjual mampu membentuk suatu hubungan kerjasama yang 
baik antara pembeli dan penjual serta merupakan kunci untuk mempertahakan hubungan kerjasama tersebut. Kepuasan nasabah adalah perasaan senang atau kecewa seseorang yang muncul setelah membandingkan kinerja (hasil) produk yang dipikirkan terhadap kinerja (hasil) yang diharapkan.

Penelitian ini menggunakan dua jenis sumber data yaitu data primer dan data sekunder. Data primer yang digunakan dalam penelitian ini adalah persepsi nasabah mengenai objek penelitian sesuai dengan indikator yang digunakan dalam penelitian ini. Data sekunder dalam penelitian ini diperoleh dari berbagai sumber seperti PT. Prudential pusat Bali, jurnal-jurnal ilmiah dan PT Satwika Purwa Negara. Selain itu penelitian ini juga menggunakan dua jenis data yaitu data kualitatif dan data kuantitatif. Data kualitatif, yaitu data yang disajikan dalam bentuk kata verbal bukan dalam bentuk angka. Data kualitatif dalam penelitian ini yaitu gambaran umum objek penelitian dan persepsi nasabah mengenai objek penelitian sesuai dengan indikator yang digunakan dalam penelitian ini. Data kuantitatif adalah jenis data yang dapat diukur atau dihitung secara langsung, yang berupa informasi atau penjelasan yang dinyatakan dengan bilangan atau berbentuk angka usia responden dan hasil tabulasi tanggapan responden dari daftar pertanyaan yang ada dalam kuesioner.

Populasi dalam penelitian ini adalah seluruh nasabah PT.Satwika Purwa di kota Denpasar yang berjumlah 8.487 orang. Teknik pengambilan sampel pada penelitian ini menggunakan teknik purposive sampling. Menurut Kasiram (2010) teknik purposive sampling mementingkan ciri atau sifat-sifat tertentu yang dipandang mempunyai sangkut paut yang erat dengan ciri-ciri atau sifat populasi 
yang sudah diketahui sebelumnya. Jumlah anggota sampel sering dinyatakan dengan ukuran sampel. Jumlah sampel yang diharapkan 100\% mewakili populasi adalah jumlah anggota populasi itu sendiri. Untuk jumlah populasi yang terlalu banyak akan kita ambil untuk dijadikan sampel dengan harapan jumlah sampel yang kita ambil dapat mewakili poopulasi yang ada. Teknik ini tidak memberikan kesempatan yang sama pada semua populasi untuk dijadikan sampel.

Berdasarkan hasil perhitungan dengan menggunakan rumus slovin, diperoleh hasil sebesar 98,835, sehingga jumlah sampel yang digunakan adalah 100 orang setelah dibulatkan. Kelemahan dari teknik penarikan sampel dengan cara ini adalah sampel yang terpilih kemungkinan besar tidak mewakili populasi, sehingga generalisasi yang dapat dilakukan oleh peneliti akan terbatas. Cara ini juga cenderung memiliki bias yang tinggi karena peneliti menentukan sendiri responden yang terpilih secara acak yang biasanya dengan subjektif. Metode pengumpulan data yang digunakan pada penelitian ini adalah kuesioner, kuesioner merupakan teknik pengumpulan data yang dilakukan dengan cara memberikan daftar pernyataan tertulis kepada para responden untuk dijawab, baik pernyataan yang sifatnya tertutup maupun terbuka. Bentuk dari kuesioner juga bermacammacam bisa melalui surat lampiran ataupun melaui internet, biasanya kuesioner baik digunakan apabila jumlah responden yang digunakan cukup besar dan tersebar di berbagai wilayah.

Penelitian ini menggunakan teknik analisis jalur (path analysis). Menurut Ghozali (2013) analisis jalur merupakan perluasan dari analisis regresi linear berganda, atau analisis jalur adalah penggunaan analisis regresi untuk menaksir 
hubungan kausalitas antar variabel (model casual) yang telah ditetapkan sebelumnya berdasarkan teori. Analisis jalur digunakan untuk menentukan pola hubungan antara tiga atau lebih dan tidak dapat digunakan untuk mengkonfirmasi atau menolak hipotesis. Dasar perhitungan koefisien jalur adalah analisis korelasi dan regresi dan dalam perhitungan menggunakan software dengan program SPSS for windows.

Langkah-langkah dalam menganalisis data dengan menggunakan path analysis adalah sebagai berikut (1) merumuskan hipotesis dan persamaan structural, (2) bentuk diagram koefisien jalur, (3) menghitung koefisien jalur secara simultan (keseluruhan), (4) menghitung koefisien jalur secara individual dan (5) meringkas dan menyimpulkan. Pengujian hipotesis mediasi dapat dilakukan dengan prosedur yang dikembangkan oleh Sobel (1982) dan dikenal dengan Uji Sobel (Sobel Test). Uji Sobel digunakan dengan menguji kekuatan pengaruh tidak langsung variabel Kualitas Layanan (X) terhadap variabel Kepuasan Nasabah $\left(\mathrm{Y}_{2}\right)$ melalui variabel Kepercayaan Nasabah $\left(\mathrm{Y}_{1}\right)$. Pengaruh tidak langsung variabel Kualitas Layanan (X) terhadap variabel Kepuasan Nasabah $\left(\mathrm{Y}_{2}\right)$ melalui variabel Kepuasan Nasabah $\left(\mathrm{Y}_{1}\right)$ dihitung dengan cara mengalikan koefisien jalur $\mathrm{X}$ terhadap $\mathrm{Y}_{1}$ (a) dengan koefisien jalur $\mathrm{Y}_{1}$ terhadap $\mathrm{Y}_{2}$ (b) atau ab. Standar error koefisien a dan b ditulis dengan $\mathrm{S}_{\mathrm{a}}$ dan $\mathrm{S}_{\mathrm{b}}$, besarnya standar error tidak langsung (indirect effect) $\mathrm{S}_{\mathrm{ab}}$. 


\section{HASIL DAN PEMBAHASAN}

Uji validitas digunakan untuk mengukur sah atau valid tidaknya suatu kuesioner. Suatu kuesioner dikatakan valid jika pertanyaan pada kuesioner mampu untuk mengungkapkan sesuatu yang akan diukur oleh kuesioner tersebut. Uji validitas pada penelitian ini dilakukan terhadap variabel kualitas pelayanan, kepercayaan nasabah dan kepuasan nasabah. Hasil uji disajikan pada Tabel 2.

Tabel 2.

Hasil Uji Validitas Variabel Kualitas Pelayanan (X)

\begin{tabular}{llcl}
\hline No & \multicolumn{1}{c}{ Dimensi } & Koefisien Korelasi & Valid \\
& & 0,938 & Valid \\
\hline 1 & Tangible & 0,883 & Valid \\
2 & Reliability & 0,907 & Valid \\
3 & Responsivess & 0,863 & Valid \\
4 & Assurance & 0,943 & Valid \\
5 & Emphaty & &
\end{tabular}

Berdasarkan Tabel 2 diketahui bahwa seluruh indikator dalam variabel kualitas pelayanan memiliki koefisien korelasi yang lebih besar dari 0,3. Jadi dapat disimpulkan bahwa seluruh indikator telah memenuhi syarat validitas data.

Tabel 3.

Hasil uji validitas variabel kepercayaan nasabah (Y1)

\begin{tabular}{clcc}
\hline No & \multicolumn{1}{c}{ Indikator } & Koefisien Korelasi & Keterangan \\
\hline 1 & Integritas & 0,828 & Valid \\
2 & Kebaikan & 0,861 & Valid \\
3 & Kompetensi & 0,891 & Valid \\
\hline \multicolumn{2}{l}{ Sumber $:$ Data Diolah, 2017 } & &
\end{tabular}

Berdasarkan Tabel 3 diketahui bahwa seluruh indikator dalam variabel kepercayaan nasabah memiliki koefisien korelasi yang lebih besar dari 0,3. Jadi dapat disimpulkan bahwa seluruh indikator telah memenuhi syarat validitas data.

Tabel 4.

Hasil uji validitas variable kepuasan nasabah (Y2)

\begin{tabular}{cccc}
\hline No & Indikator & Koefisien Korelasi & Keterangan \\
\hline 1 & Tidak ada keluhan & 0,810 & Valid \\
\hline
\end{tabular}




\begin{tabular}{clll}
\hline 2 & Perasaan puas nasabah & 0,845 & Valid \\
3 & Kesesuaian dengan ekspetasi & 0,907 & Valid \\
\hline \multicolumn{2}{l}{ Sumber : Data Diolah, 2017 }
\end{tabular}

Berdasarkan Tabel 4 diketahui bahwa seluruh indikator dalam variabel kepuasan nasabah memiliki koefisien korelasi yang lebih besar dari 0,3. Jadi dapat disimpulkan bahwa seluruh indikator telah memenuhi syarat validitas data.

Reliabilitas adalah alat untuk mengukur suatu kuesioner yang merupakan indikator dari variabel atau konstruk. Suatu kuesioner dikatakan reliabel atau handal jika jawaban seseorang terhadap pernyataan adalah konsisten atau stabil dari waktu ke waktu. Untuk mengukur reliabilitas dengan uji statistik cronbach alpha lebih besar dari 0,60. Nilai Cronbach alpha ditunjukkan pada tabel berikut.

Tabel 5.

Uji Reliabilitas

\begin{tabular}{lll}
\hline Variabel & Alpa Cronbach & Keterangan \\
\hline & & \\
Kualitas pelayanna & 0,941 & Reliabel \\
Kepercayaan nasabah & 0,823 & Reliabel \\
Kepuasan nasabah & 0,815 & Reliabel \\
\hline Sumber : Data Diolah, 2017 & &
\end{tabular}

Hasil uji menunjukkan nilai cronbach alpha untuk semua variabel diatas 0,6. Sehingga dapat disimpulkan bahwa semua variabel telah memenuhi syarat reliabilitas data.

Pengujian data pada penelitian ini menggunakan analisis jalur (path analysis) guna menguji pola hubungan yang mengungkapkan pengaruh variabel atau seperangkat variabel terhadap variabel lainnya, baik pengaruh langsung maupun pengaruh tidak langsung. Analisis ini dilakukan dengan tahapan sebagai berikut. 
Secara teoritis, hubungan antar variabel dapat dibuat model dalam bentuk diagram path, sebagai berikut.

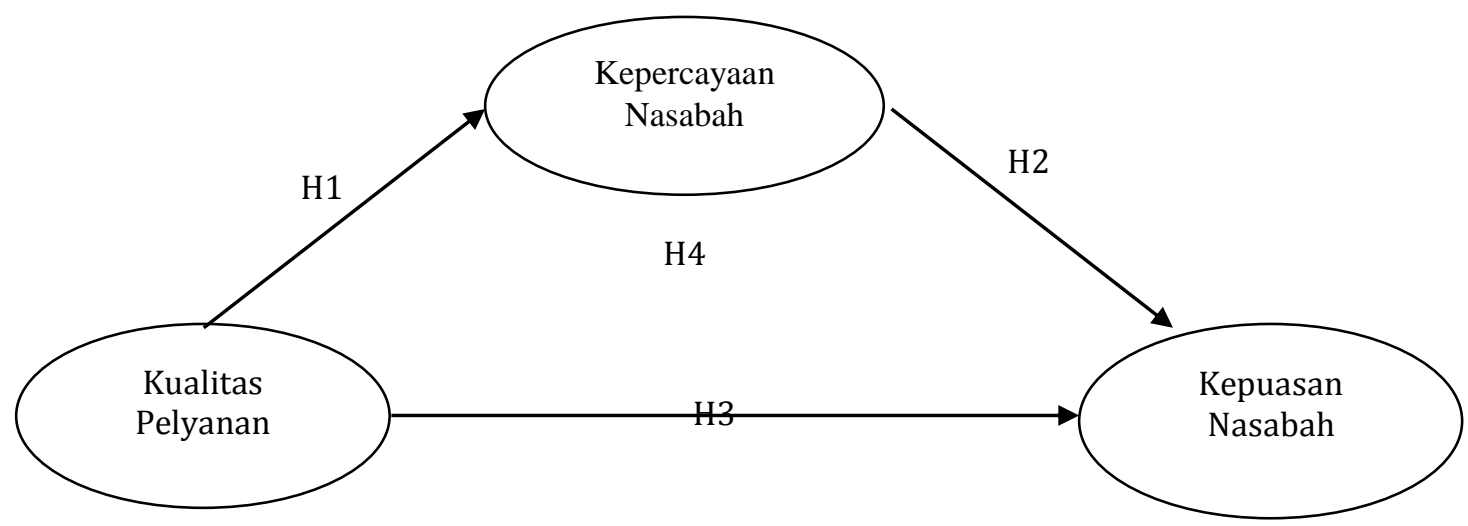

Gambar 1 Model Jalur Peran Kepercayaan Nasabah Dalam Memediasi Pengaruh Kualitas Pelayanan Terhadap Kepuasan Nasabah

Sumber : Data Diolah 2017

Model tersebut juga dapat dinyatakan dalam bentuk persamaan, sehingga membentuk sistem persamaan berikut.

$$
\begin{aligned}
& Y_{1}=\beta_{1} X_{1}+\mathrm{e} \\
& Y_{2}=\beta_{1} X_{1}+\beta_{2} Y_{1}+e
\end{aligned}
$$

Untuk pemeriksaan terhadap asumsi ini, dapat dilakukan dengan melihat susunan model teoritis yang telah dibangun dengan memperlihatkan bentuk hubungan antar variabel adalah linier, yaitu sistem aliran ke satu arah, dimana hubungan antara ei saling bebas demikian juga hubungan antara ei dengan variabel $\mathrm{x}$ saling bebas, dan tidak ada variabel endogen yang mempunyai pengaruh bolak balik.

Penelitian ini dalam analisis jalur, pengaruh langsung dinyatakan dengan koefisien $\rho_{\mathrm{i}}$, sedangkan pengaruh tidak langsung dan pengaruh total dapat dihitung dengan membuat perhitungan tersendiri. Berdasarkan perhitungan 
terhadap substruktur 1, dan 2, maka dapat diketahui besarnya pengaruh langsung, pengaruh tidak langsung dan pengaruh total antar variabel. Perhitungan pengaruh antar variabel adalah sebagai berikut.

Tabel 6.

Pengaruh Langsung, Pengaruh Tidak Langsung Dan Pengaruh Total

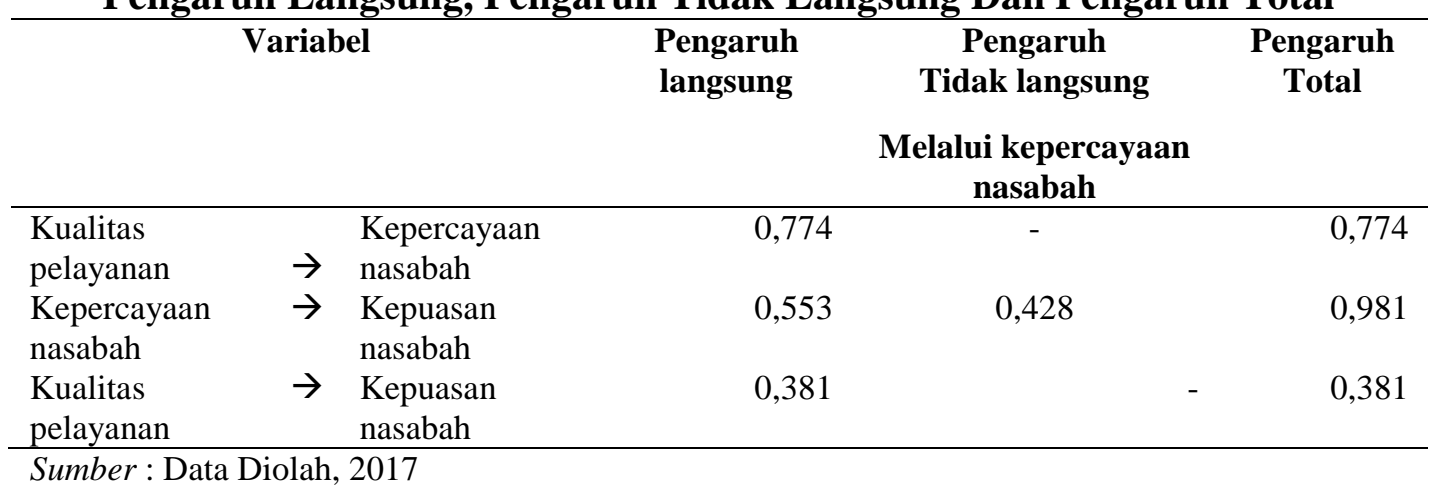

Ada dua indikator untuk melakukan pemeriksaan validitas model, yaitu koefisien determinasi total dan theory triming dimana hasilnya dapat disajikan sebagai berikut. keragaman data yang dapat dijelaskan oleh model adalah sebesar 91,0 persen atau dengan kata lain informasi yang terkandung dalam data sebesar 91 persen dapat dijelaskan oleh model, sedangkan sisanya yaitu 9 persen dijelaskan oleh variabel lain (tidak terdapat dalam model) dan error.

Pendekatan ini dilakukan dengan membuang jalur-jalur yang non signifikan agar memperoleh model yang benar-benar didukung oleh data empirik. Uji validasi pada setiap jalur untuk pengaruh langsung adalah sama dengan regresi, menggunakan nilai $\mathrm{p}$ dari uji $\mathrm{t}$ yaitu pengujian koefisien regresi variabel dibakukan secara parsial dengan kualitas pelayanan (X) terhadap kepercayaan (Y1) adalah 12,085 sig 0,00, kualitas pelayanan (X) terhadap kepuasan nasabah (Y2) adalah 5,051 dengan sig 0,00, variabel kepercayaan nasabah terhadap 
kepuasan nasabah sebesar 7,325 dengan sig 0,00.

Berdasarkan hasil perhitungan diperoleh taraf signifikansi penelitian untuk variabel kualitas pelayanan terhadap keperycaan sebesar $0,000<0,05$, sehingga H0 ditolak dan H1 diterima, dengan kata lain kualitas pelayanan berpengaruh signifikan terhadap keperycaan nasabah pada PT. Satwika Purwa Negara. Hasil penelitian menunjukkan semakin baik kualitas pelayanan maka semakin tinggi tingkat kepercayaan nasabah.

Penelitian ini didukung oleh Pramana dan Rastini (2016), Agustiono dan Sumarno (2006), Wang I-Ming dan Shieh (2006), Aryani dan Rosinta (2010), Paramitha dkk. (2013) menghasilkan bahwa semakin tinggi tingkat kualitas pelayanan yang diberikan, maka semakin tinggi pula kepercayaan yang diterima oleh nasabah pada suatu perusahaan.

Berdasarkan hasil perhitungan diperoleh taraf signifikansi penelitian untuk variabel kepercayaan terhadap kepuasan nasabah sebesar $0,000<0,05$, sehingga H0 ditolak dan H2 diterima, dengan kata lain kepercayaan berpengaruh signifikan terhadap kepuasan nasabah PT. Satwika Purwa Negara. Hasil penelitian menunjukkan semakin tinggi kepercayaan nasabah maka semakin tinggi tingkat kepuasan nasabah.

Hasil penelitian ini didukung oleh Wardani (2015) mengenai pengaruh kepercayaan dan kepuasan terhadap loyalitas, membuktikan bahwa adaya hubungan yang positif antara kepercayaan terhadap kepuasan nasabah, dan penelitian yang dilakukan oleh Arifin (2011) pengaruh kepercayaan dan kualitas 
Ida Bagus Ngurah Satwika Purwa Peran Kepercayaan...

pelayanan terhadap kepuasan konsumen, membuktikan bahwa kepercayaan berpengaruh positif terhadap kepuasan nasabah.

Berdasarkan hasil perhitungan diperoleh taraf signifikansi penelitian untuk variabel kualitas pelayanan terhadap kepuasan kerja sebesar $0,00<0,05$, sehingga H0 ditolak dan H3 diterima, dengan kata lain kualitas pelayanan berpengaruh signifikan terhadap kepuasan nasabah PT. Satwika Purwa Negara. Hasil penelitian menunjukkan semakin baik kualitas pelayanan maka semakin tinggi tingkat kepuasan nasabah.

Hasil penelitian ini didukung oleh Aryani dan Rosita (2010) mengenai pengaruh kualitas pelayanan dalam membentuk loyalitas pelanggan membuktikan bahwa, kualitas pelayanan berpengaruh positif dan signifikan terhadap kepuasan pelanggan, begitu pula penelitian yang dilakukan oleh Caruana (2002) membuktikan bahwa terdapat hubungan yang erat antara kualitas pelayanan dan kepuasan.

Berdasarkan hasil perhitungan diperoleh $Z_{\text {hitung }}(6,21)>Z$ tabel $(1,96)$ sehingga $\mathrm{H} 0$ ditolak dan $\mathrm{H}_{4}$ diterima, dengan kata lain kepercayaan nasabah merupakan variabel mediasi yang menghubungkan kualitas pelayanan dengan kepuasan nasabah pada PT. Satwika Purwa Negara. Hasil penelitian ini didukung Didukung oleh penelitian sebelumnya yang dilakukan oleh Santosa (2011) membuktikan bahwa pengaruh kualitas pelayanan terhadap kepuasan nasabah dengan kepercayaan sebagai variabel mediasi berpengaruh positif dan signifikan. Penelitian yang dilakukan Lyle (2002), yang berjudul Trust, Satisfactioin and Loyalty in Customer Reliationship Management : An Application of Justice 
Theory, hasilnya menunjukkan bahwa kepercayaan mampu memperkuat pengaruh kepuasan terhadap loyalitas nasabah.

\section{SIMPULAN DAN SARAN}

Simpulan yang dapat diberikan berdasarkan hasil penelitian dapat disimpulkan sebagai berikut. Kualitas pelayanan berpengaruh signifikan terhadap kepercayaan nasabah pada PT. Satwika Purwa Negara. Kepercayaan nasabah berpengaruh singifikan terhadap kepuasan nasabah pada PT. Satwika Purwa Negara. Kualitas pelayanan berpengaruh signifikan terhadap kepuasan nasabah PT. Satwika Purwa Negara. Kepercayaan nasabah dapat memediasi hubungan kualitas pelayanan dengan kepuasan nasabah pada PT. Satwika Purwa Negara dengan baik. Membuktikan bahwa pengaruh kualitas kualitas pelayanan terhadap kepuasan nasabah dengan kepercayaan sebagai variabel mediasi berpengaruh positif dan signifikan.

Adapun saran yang dapat diberikan berdasarkan hasil penelitian, dengan kepercayaan nasabah sebagai faktor mediasi pengaruh kualitas pelayanan terhadap kepuasan nasabah PT. Satwika Purwa Negara. Kedisiplinan petugas, penggunaan alat bantu, dan kemudahan dalam pelayanan harus lebih di optimalkan, agar keperluan nasabah cepat dapat di tanggapi. Memiliki standar pelayanan yang jelas dan kemampuan petugas atau apparatus dalam menggunakan alat bantu dalam proses pelayanan harus lebih di tingkatkan, agar nasabah lebih mudah untuk melakukan klaim. Ketepatan petugas dalam melakukan pelayanan dengan tepat waktu dan kecepatan petugas dalam melakukan pelayanan harus lebih di 
tingkatkan, agar dapat mengurangi antrean nasabah. Jaminan kepastian biaya dan legalitas yang diberikan petugas dalam pelayanan harus lebih ditingkatkan, agar nasabah lebih mudah menyiapkan kewajiban yg hendak di lakukan sebelum melakukan klaim. Petugas melayani dengan tidak diskriminatif dan selalu mendahulukan kepentingan nasabah agar lebih di tingkatkan, agar nasabah tidak merasa di beda bedakan. Integritas dan kompetensi PT. Satwika Purwa Negara harus lebih di tingkatkan agar kepuasan nasabah lebih mudah dicapai.

\section{REFERENSI}

Agustiono, B. dan Sumarno. 2006. Analisis Pengaruh Kualitas Pelayanan Jasa Terhadap Kepuasan dan Loyalilas Pasien Rawat Inap di Rumah Sakit ST. Elisabeth Semarang. Jurnal Ilmiah Kopertis, 1(1), h: 1-18.

Afiatin, T. dan Martaniah, S.M. 1998. Peningkatan Kepercayaan Diri Remaja Melalui Konseling Kelompok. Jurnal Psikologika, 3(6), h: 66-79.

Akbar, M.M. dan Parvez, N. 2009. Impact of Service Quality, Trust, and Customer Satisfaction on Customer Loyalty. ABAC Journal, 29(1), h: 2438 .

Anderson, J.C. dan James A. N, 1990, A Model of Distributor Firm and Manufacturer Firm Working Partnerships, Journal of Marketing, 54(2), h: 42-58.

Arifin, Samsul. 2011. Pengaruh Kepercayaan, Fasilitas, dan Kualitas Pelayanan Terhadap Kepuasan Konsumen Pada Hotel Jepara Indah. Jurnal Dinamika Ekonomi dan Bisnis, 8(1), h: 67-78.

Aryani, D. dan Rosinta, F. 2010. Pengaruh Kualitas Layanan terhadap Kepuasan Pelanggan dalam Membentuk Loyalitas Pelanggan. Bisnis \& Birokrasi, Jurnal Ilmu Administrasi dan Organisasi, 17(2), h: 114-126.

Azwar, Saifuddin. 2011. Reliabilitas dan Validitas, edisi ketiga. Yogyakarta: Pustaka Pelajar.

Barata, A.A. 2003. Dasar-Dasar Pelayanan Prima. Jakarta : Elex Media Kompetindo. 
Birgelen, Marcel van, Ko de Ruyter dan Martin Wetzels (2000) : The Impact of Incomplete Information on the Use of Marketing Research Intelligence in International Service Settings, Journal of Service Research, 2(4), h: 372387.

Brady, K.M., Cronin Jr. 2001. Some New Thoughts On Conceptualizing Perceived Service Quality: A Hierrarchial Approach. The Journal of Marketing, 6(5), h: 34-49.

Caruana, A. 2002. Service Loyalty: The Effects of Service Quality and the Mediating Role of Customer Satisfaction. European Journal of Marketing, 36(8), h: 811-828.

Doney, P.M. and Cannon J.P. 1997, An Examination of the nature of Trust in Buyer-Seller Relationships. Journal of Marketing, 61(2), h: 35-51.

Ellitan, L. 2006. Strategi Inovasi dan Kinerja PerusahaanManufaktur di Indonesia: Pendekatan Model Simultan dan Model Sekuensial. Jurnal Manajemen, 6(1), h: 1-20.

Gatot Yulianto, Purwanto Waluyo, 2004, Pengaruh Keefektifan Komunikasi, Kualitas Teknikal, Kualitas Fungsional dan Kepercayaan Pada Komitmen Keterhubungan Bandara Ahmad Yani Semarang, Telaah Manajemen, Magister Manajemen STIE Stikubank Semarang, 1(3), h: 31-42.

Gefen, D., Karahanna, E. and Straub, D.W. Trust and TAM in Online Shopping: An Integrated Model. 2003. Dalam Yee, Beh Yin dan Faziharudean, T.M. Factors Affecting Customer Loyalty of Using Internet Banking in Malaysia. Journal of Electronic Banking Systems, 27(1), h: 51-90.

Ghozali, Imam. 2013. Aplikasi Analisis Multivariate Dengan Program SPSS. Semarang: Badan Penerbit Universitas Diponegoro.

Hamdani, Lupiyoalandi. 2006. Manajemen Pemasaran Jasa, Edisi Kedua. Jakarta: Penerbit Salemba Empat.

Haryono dan Syafiq, Ali. 2010. Analisis Pengaruh Kualitas Layanan, Kepercayaan dan Kepuasan Terhadap Loyalitas Pelanggan Telkom Speedy dengan Metode Structural Equation Modeling. Tesis Sarjana Jurusan Manajemen Industri pada Institut Teknologi Sepuluh November, Surabaya.

Kasiram, Moh. 2010. Metodologi Penelitian Kuantitatif-Kualitatif, Malang: UINMaliki Press. 
Ida Bagus Ngurah Satwika Purwa Peran Kepercayaan...

Kotler, Philip. 2002. Manajemen Pemasaran di Indonesia : Analisis, Perencanaan, Implementasi dan Pengendalian. Salemba Empat. Jakarta.

2009. Manajemen Pemasaran edisi 13. Indonesia: PT Macanan Jaya Cemerlang.

Lyle R. Wetsch, 2002, Trust, Satisfaction and Loyalty in Customer Reliationship Management: An Application of Justice Theory, School of Business-Goodes Hall, Queen's University Kingston, Ontario, Canada. Journal of Relationship Marketing. 4(3), h: 29-42.

Moenir. 2002. Manajemen Pelayanan Umum Indonesia.Bumi Aksara. Jakarta.

Morgan, R.M. and Hunt, S.D. 1994, The commitment-trust theory of relationship marketing, Journal of Marketing, 58(3), h: 20-38.

Paramitha, A.A.A, Rahyuda, I.Kt. dan Suasana, I.G.A.K. 2013. Pengaruh Kualitas Layanan Terhadap Kepuasan dan Loyalitas Pelanggan Garuda Indonesia di Denpasar. Jurnal Manajemen, Strategi Bisnis dan Kewirausahaan, 7(1), h: 19-28.

Parasuraman, A. Valerie, 2001. (Diterjemahkan oleh Sutanto) Delivering Quality Service. The Free Press, New York.

Prabowo, Muhamad Ismail. 2010. Pengaruh Kualitas Pelayanan, Citra Perusahaan, Kepercayaan Dan Kepuasan Terhadap Loyalitas Nasabah (Studi Kasus Pada Nasabah Bank Bri Cabang Sragen). Skripsi Sarjana Jurusan Manajemen pada Fakultas Ekonomi Universitas Sebelas Maret, Surakarta.

Pramana, Yogi; Rastini, Made 2016. Pengaruh kualitas pelayanan terhadap kepercayaan nasabah dan loyalitas nasabah bank mandiri cab. Veteran Denpasar Bali. Skripsi Sarjana Jurusan Manajemen pada Fakultas Ekonomi dan Bisnis Universitas Udayana, Bali.

Rangkuti, Fredy. 2006. Teknik Mengukur dan Strategi Meningkatkan Kepuasan Pelanggan. Jakarta : Penerbit PT Gramedia Pustaka Utama.

Rizan, Mohhamad dan Fajar Andika. 2011. Pengaruh Kualitas Produk dan Kualitas Pelayanan Terhadap Kepuasan Pelanggan (Survei Pelanggan Suzuki Dealer Fatmawati Jakarta Selatan). Jurnal Mahasiswa Q-MAN, 1 (3), h: 28-43.

Santosa, G, Heru. 2011. Analisis Pengaruh Kualitas Pelayan Terhadap Kepuasan Nasabah dengan Kepercayaan Sebagai Variabel Intervening pada PT. Bank Rakyat Indonesia (persero) Tbk. Kantor Cabang Wonogiri. Tesis program 
Magister Manajemen Program Pasca Sarjana Universitas Sebelas Maret, Surakarta.

Sekaran, Uma. 2006. Research Methods for Business; Metodologi Penelitian untuk Bisnis. Edisi ke 4. Jakarta: Salemba Empat.

Sugiyono, 2011. Metode penelitian kuntitatif kualitatif dan $R \& D$. Alfabeta. Bandung.

Surya, H. 2009. Menjadi Manusia Pembelajar. Jakarta: PT Elex Media Komputindo.

Sobel, M. E. 1982. Asymptotic confidence intervals for indirect effect in structural equation models. In S. Leinhardt (Ed.), Sociological Methodology. Washington DC: American Sociological Association. Journal Article. 13, h: 290-312.

Spencer, Peter M., \& Signe M. Spencer. 1993. Competence at Work. Models for Superior Performance. New York: Jhon Wiley \& Sons Inc.

Syamsi. 2008. Pengaruh Kualitas Pelayanan Jasa Terhadap Kepuasan Konsumen Pada Siswa Bimbingan dan Konsultasi Belajar Al Qolam Bandarlampung. Jurnal Ekonomi \& Pendidikan, 5(1), h: 18-36.

Tjiptono, Fandy. 2007. Strategi Pemasaran. Edisi Pertama. Andi Ofset. Yogyakarta.

2008. Strategi Pemasaran: Edisi 3. Yogyakarta : Andi Offset

Tjiptono, Fandy dan Chandra, Gregorious. 2011. Service, Quality \& Satisfication. Edisi 3. Yogyakarta : C.V Andi Offset.

Wahyuningsih, Anis. 2002. Analisa Tingkat Kepuasan Konsumen Berdasarkan Kualitas Pelayanan pada Rumah Sakit Umum Kabupaten Karang Anyer. Skripsi. Sarjana Fakultas Ekonomi Program Studi Manajemen UMS. Jakarta.

Wang, I-Ming dan Shieh, Chich-Jen. 2006. The Relationship between Service Quality and Customer Satisfaction: The Example of CJCU Library. Journal of Information and Optimization Sciences, 27(1), h: 193-209.

Wardani. S, Rachma. 2015. Pengaruh Kepercayaan Dan Kepuasan Terhadap Loyalitas Jamaah Umroh PT. Nur Ramadhan Yogyakarta. Skripsi Sarjana Jurusan Manajemen Dakwah pada Fakultas Dakwah dan Komunikasi Universitas Islam Negeri Sunan Kalijaga. Yogyakarta. 
Ida Bagus Ngurah Satwika Purwa Peran Kepercayaan...

Winarsih, Ratminto., Atik Septi. 2010. Manejemen Pelayanan. Yogyakarta: Pustaka Pelajar.

Zethaml, Valarie, Mary Jo. B., Dwayne D.G. 2013. Service Marketing. McGrawHill International Edition. 